\title{
Humanização do Parto: Caminhos para a Implantação de um Centro de Parto Normal em um Hospital de Porto Alegre-RS
}

\author{
Sarges, Roniele Costa; Pedroso, Clarissa N. L. da Silva; López, Laura Cecilia \\ Unisinos — roniele_sarges@yahoo.com.br
}

Introdução: o parto constituía um evento compartilhado na esfera familiar, principalmente entre mulheres. no entanto, com o avançar das tecnologias, este passou a ser institucionalizado em hospitais, o que resultou no desempoderamento da mulher e transferiu ao médico e à instituição hospitalar todo o poder sobre o corpo feminino. Esse panorama da atenção ao parto no Brasil levou o governo a criar diversos programas e políticas visando à redução das taxas de morbimortalidade materna e infantil e humanização do cuidado. Assim, foi criada a Rede Cegonha ( $R C)$, que prevê a criação dos Centros de Parto Normal (CPN). Nesse contexto, é pertinente a problematização das questões que surgem deste possível processo de transição paradigmática de modelos de atenção. Objetivos: Analisar o processo de implantação de estratégias que visam humanizar o parto e nascimento em uma maternidade pública de Porto Alegre/RS, buscando identificar transformações institucionais referentes a modelos e práticas de cuidado, com foco na implantação do CPN e buscando examinar a trajetória de atuação, de formação e de engajamento dos profissionais de saúde envolvidos nesse processo; compreender as concepções desses profissionais acerca da humanização do parto; investigar como esse novo modelo é entendido e incorporado pela equipe em suas práticas e cuidados e observar como os profissionais de saúde lidam com as tensões geradas pela reorganização dos papéis de cada um e de suas responsabilizações. Método: a pesquisa será qualitativa com abordagem etnográfica, desenhada como estudo de caso. a coleta de dados se dará por meio de entrevistas etnográficas realizadas com os profissionais de saúde envolvidos no processo. Além disso, serão realizadas observações participantes na maternidade e em eventos e reuniões, públicas e de equipe, onde esteja sendo discutidas as questões inerentes a humanização do parto e nascimento. para o registro de dados, será utilizado o diário de campo. Os dados serão organizados e analisados de forma que dialoguem com as categorias teóricas, confrontando-os entre si e com a literatura. Frente aos dados extraídos das entrevistas, será adotado o método de análise de discurso. Resultados: uma primeira aproximação ao campo se deu em um fórum para tratar e discutir as estratégias necessárias à implantação da $\mathrm{RC}$ nas maternidades. o evento reuniu estudantes, enfermeiros, médicos e representantes de ambos os conselhos. As discussões presenciadas revelaram uma dificuldade, por parte das equipes médicas, em aderir ao modo de funcionamento do CPN, deixando claras as tensões geradas, nos profissionais de saúde e em suas corporações, por conta das transformações previstas com a implantação de um CPN. Conclusão: Espera-se que os resultados mostrem se, de fato, está havendo mudança, além de expor os nós críticos que precisam ser trabalhados na busca de uma assistência humanizada e que corrobore com o previsto nos projetos governamentais para a atenção ao parto e nascimento.

Sarges, Roniele Costa; Pedroso, Clarissa N. L. da Silva; López, Laura Cecilia. Humanização do Parto: Caminhos para a Implantação de um Centro de Parto Normal em um Hospital de Porto Alegre-Rs. In: Anais do Congresso Internacional de Humanidades \& Humanização em Saúde [= Blucher Medical Proceedings, num.2, vol.1]. São Paulo: Editora

Blucher, 2014. ISSN 2357-7282

DOI 10.5151/medpro-cihhs-10365 